\title{
A Cleaner Mining Method for Waste Tailings as Paste Materials to Goafs
}

\author{
Yuxi Liu $\mathbb{D}^{\mathbb{D}},{ }^{1,2}$ Zhixiang Liu $\mathbb{D}^{2},{ }^{2}$ Keming Li, ${ }^{2}$ Sijia Deng $\mathbb{D}^{2},{ }^{2}$ and Longjun Dong $\mathbb{D}^{2}$ \\ ${ }^{1}$ Engineering Faculty, Monash University, Melbourne 3800, Australia \\ ${ }^{2}$ School of Resources and Safety Engineering, Central South University, Changsha 410083, China \\ Correspondence should be addressed to Longjun Dong; lj.dong@csu.edu.cn
}

Received 7 August 2020; Revised 2 September 2020; Accepted 22 September 2020; Published 22 October 2020

Academic Editor: Yanlin Zhao

Copyright (C) 2020 Yuxi Liu et al. This is an open access article distributed under the Creative Commons Attribution License, which permits unrestricted use, distribution, and reproduction in any medium, provided the original work is properly cited.

\begin{abstract}
Underground mining is the primary method to obtain economically valuable minerals, but it usually brings a large number of goafs (mined-out voids) and large quantities of waste tailings. The gradual accumulation of mine tailings has attracted worldwide attention because of its occupation and acidification of land, and a large number of goafs often lead to stope instability and ground subsidence. To solve the waste tailing accumulation and ground subsidence, a cleaner mining method-cemented tailing backfilling (CTB) - for filling mining goafs by tailings was proposed. Firstly, the volume of the goafs was detected, and the hydraulic-mechanical coupling properties of the original tailings were tested. Then, a reasonable mix proportion of tailings, binder, and water was determined based on laboratory experiments. Finally, the filling pipe network and filling system were designed according to the actual situation of the mine. This paper provides an environmental and economic method for treating tailing accumulation and preventing ground subsidence. At the same time, it was demonstrated in Linglong Gold Mine (LLGM), and a plan which allows 15.8 service years of nondischarge of tailings was designed in LLGM.
\end{abstract}

\section{Introduction}

The management of mine tailings is a serious environmental issue in various countries [1]. Currently, the mineral resources extraction and the mining scale have constantly expanded to meet the growing demand for consumption [2, $3]$, which results in the increasing amount of solid tailing waste [4]. A large amount of tailings not only occupies the land but also poisons and acidifies the land $[5,6]$, which causes serious threats to the lives and property of people [7-9]. At the same time, underground mining often leads to stope instability and ground subsidence [10-12], causing damage to residential buildings and infrastructures [13]. The accumulation of tailings in China is close to 20 billion tons which ranking first in the world, and the subsidence area caused by mining activity has reached $314,765 \mathrm{~km}^{2}$, resulting in 535 deaths and economic losses of $\$ 1.9$ billion [14]. The issue has aroused the high attention of the national government. In the 18th national congress of the communist party of China (18th CPC National Congress), the Chinese govern- ment highlights the construction of ecological civilization at the top of the list.

To solve this problem, many scholars carried out a lot of experiments and developed a large number of methods, including (a) covering the tailings with soil for growing plants [15], (b) constructing tailing dam to storage tailings [16], (c) filling the tailings into the goafs [17], and (d) chemical treatment of tailings [18]. Some treatment approaches have been adopted to deal with tailings [19]; however, some methods are not widely used because of significant increases in costs [20]. The tailing storage is reaching the limit, and 1,886t of new tailings need to be processed every day in LLGM. The environmental and economic method to treat accumulation of mine tailings in LLGM is back fill technology, which fills the underground goafs with CTB [21]. The main purposes of stope backfill are (a) improving the working environment [22], (b) preventing surface subsidence [23], (c) reducing ore dilution and mining cycles [24], and (d) mitigating the surface storing problem of tailings [25]. Meanwhile, CTB has lower operating costs and higher strength acquisition compared with 
other backfill technologies [26]. The $60-75 \%$ of the mining waste could be consumed by applying the CTB technology [27]. In fact, the best method of dealing with tailings is to backfill the goafs, and the best strategy to prevent surface subsidence is to use the tailings [28]. Therefore, the solid tailing waste and the goafs are the resources of each other [29]. Figure 1 shows the schematic diagram of cemented tailing backfill. Today, filling the tailings into the goafs is considered a green, environmentally, friendly, and efficient model [30, $31]$, which can meet the people's requirements for mining environmental protection and ecological balance [32].

The concentration of classified tailings is $50-60 \%$, low concentration filling slurry on the pipe wear more serious with the deepening of the mining [33]. Therefore, the mining processes need to be improved with the full tailings filling technology to achieve safe and efficient recovery [34, 35]. Compared with classified tailings, the advantage of full tailings is that the raw materials are more widely, and the utilization of tailings is higher $[36,37]$. In this study, a more economical and cleaner method was proposed, and the specific steps are shown in Figure 2.

This study selected the address of the application experiments at the Linglong Gold Mine (LLGM), because the LLGM has a large number of accumulated tailings and goafs. The LLGM is located in Shandong province including Jiuqu mining area and Xishan mining area. The tailings account for 96 percent in early process of LLGM mining gold mine, filling $67 \%$ of the tailings back to new goafs and nearly $33 \%$ of the tailings can be filled to the early goafs and deposed laneway [38]. The early goafs of LLGM have the characteristics of strongly concealed, spatial distribution is not obvious, and the roof collapses [39]. The various detection techniques were analyzed and compared based on five main factors: safety, convenience, good working environment, low cost, and high accuracy [40]. Finally, the MDL C-ALS device was used to detect the goafs [41]. The final three dimensional data coordinates, shape, and volume of goafs have been obtained based on the analysis of the scanned data. Result is in accordance with the actual shape of the goafs. C-ALS system can be used to scan goafs automatically from all directions. Then, a threedimensional model can be built automatically for the goafs based on the obtained data [42]. The results show that the volume of goafs was 5.2 million $\mathrm{m}^{3}$, and the volume of deposed laneway was 0.32 million $\mathrm{m}^{3}$, which is the precondition for backfilling the tailings. Chemical compositions and physical properties of tailings were detected [43]. Then, the most economical and environmental mix proportion was obtained by compressive strength tests $[44,45]$. In order to realize the rapid subsidence of the full tailings in the tailing towers and reduce settling time, rapid subsidence tests were carried out [46]. At the same time, a lot of tailings need to be backfilled quickly into the goafs; therefore, rapid solidification tests were carried out [47]. Finally, the backfill plan was designed by the test results and demonstrated by the application experiment.

\section{Materials and Methods}

2.1. Tailings. The tailing samples used in this study were collected from the processing plant of LLGM, which spe-

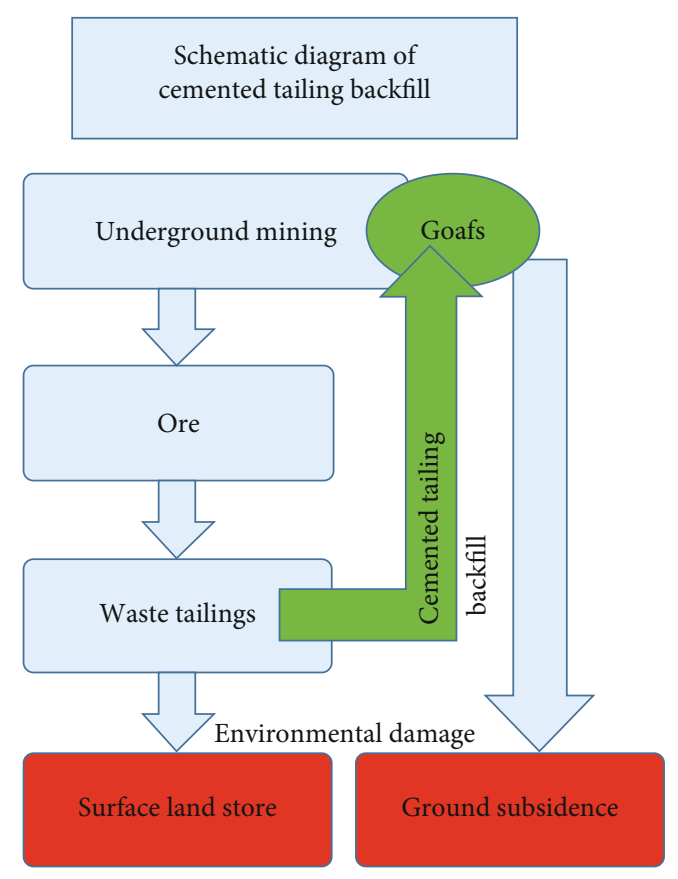

Figure 1: Schematic diagram of cemented tailing backfill.

cific gravity is $2.78 \mathrm{~g} / \mathrm{HC}^{3}$, bulk density is $1.24 \mathrm{~g} / \mathrm{HC}^{3}$, porosity is $46.5 \%$, and permeability coefficient is 0.00623 $\mathrm{HC} / \mathrm{s}$. Particle size distributions, as the most significant physical characteristic of filling material of tailings [48], were analyzed using a Mastersizer2000 laser particle size analyzer[49]. Figure 3 and Table 1 show the particle size distributions of the tailings.

According to the Tabor Study conclusion, the ratio of $\mathrm{Cu}=d 60 / d 10$ is used as the particle size distributions nonuniform coefficient [50]. The nonuniform coefficient of the tailings is 12.73 . Therefore, it is easy to transport in filling pipe and can reduce the separation of cement.

Another important characteristic of tailings is its chemical composition, which has a pronounced effect on the hardening process of backfill [51]. The mineralogical analysis of tailings and homemade cement was performed via an IEMENS D500 X-ray fluorescence spectrometer, and the result is given in Table 2 .

The main elements of the tailings are $\mathrm{Ca}(25.1 \%), \mathrm{Si}$ (11.2\%), $\mathrm{Al}$ (6.10\%), and $\mathrm{Mg}$ (4.87\%), indicating the high quality and activity of tailings. The sulfide content is very low, indicating that the strength of cemented filling is not affected, and the raw materials are environmental $[52,53]$.

2.2. Binders and Water. Homemade cement (HC) which was made by LLGM was chosen as the binder in this study. The function of homemade cement is similar to that of ordinary portland cement. Compared with ordinary portland cement, $\mathrm{HC}$ is stronger and more affordable. The chemical compositions of $\mathrm{HC}$ are listed in Table 2. Tap water was used to mix the binder and tailings in the laboratory.

2.3. Compressive Strength Tests and Bleeding Tests. The ratio of HC to tailings is $1: 4,1: 6,1: 8,1: 10,1: 12,1: 16,1: 20$, and 


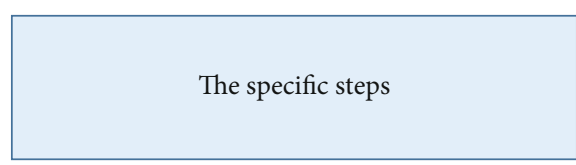

(i) Detecting goaf

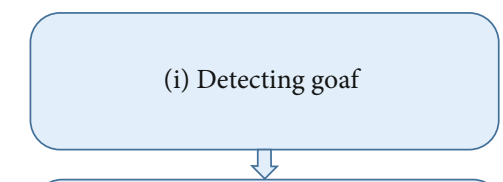

(ii) Physical characteristic of tailings

(iii) Rapid solidification tests and Rapid subsidence tests

(iv) Designing of cleaner mining method

\section{1}

(v) Application experiments

Figure 2: The specific steps of more economical and cleaner method.

$1: 30$, and the mass concentration is $65 \%, 67 \%, 70 \%$, and $75 \%$ in laboratory. The mixed slurry was injected into the plastic molds of internal dimension $70 \mathrm{~mm} * 70 \mathrm{~mm} * 70 \mathrm{~mm}$. After $24 \mathrm{~h}$ of precoagulation, test blocks were taken out of the molds and moved into the box with constant temperature and humidity. For each $\mathrm{HC} /$ tailing ratio and mass concentration, there were three different curing periods: $3 \mathrm{~d}, 14 \mathrm{~d}$, and $28 \mathrm{~d}$. Then, the test blocks were subjected to compressive strength tests using a machine with $50 \mathrm{kN}$ loading capability at a displacement rate of $1 \mathrm{~mm} / \mathrm{min}$. The mean value of each set of triplicate test blocks was selected as the overall outcome.

The bleeding rates are different with variable cement and water contents. In bleeding tests, slurry was poured into a $1000 \mathrm{ml}$ graduated cylinder. Bleeding rate was measured according to the final bleed water on the sample surface, divided by initial water volume.

2.4. Rapid Solidification Tests. The amounts of tailings in LLGM are huge. In order to reduce the maintenance time, sodium aluminate cements quick-setting agent (SCQA) was added; its main working principle is to convert the gypsum in cement into $\mathrm{Na}_{2} \mathrm{SO}_{4}$. The test mass concentrations depend on the results of compressive strength tests and bleeding tests. SCQA which the content was $3 \%, 4 \%$, and $5 \%$, respectively, was added. The experimental method and the uniaxial compression test method are the same, and the curing time is 1 day, 3 days, and 7 days, respectively.
2.5. Rapid Subsidence Tests. In general, the natural subsidence of tailings is slow. In order to realize the rapid subsidence of the full tailings in the tailing towers, polyacrylamide cationic is considered as flocculants to be added. The polyacrylamide cationic (molecular weight 15 million) was selected in test. The flocculants of $0.02 \%$, $0.03 \%$, and $0.05 \%$ concentration, respectively, were prepared. Finally, the slurry was poured into the $1000 \mathrm{ml}$ graduated cylinder. To evaluate the settlement behavior of mixtures, different calibration times were recorded, and readings were taken at $50 \mathrm{ml}$ intervals.

\section{Results and Discussions}

3.1. Optimum Mix Formulation of the Homemade Cement and Water. The test results of average compressive strength in different mass concentrations and different HC-tailing ratios were shown in Table 3 .

The results showed that $\mathrm{HC}$ is the decisive factor of the cemented filling. The compressive of test blocks depended on the $\mathrm{HC}$ concentration, and the mass concentrations had a small impact. While the HC concentration is the same, compressive strength is positively correlated with curing time and mass concentrations. The strength of the test blocks with a curing period of 28 days is higher than that of the test blocks with a curing period of 7 days, and the higher the mass concentration, the more significant the effect is. According to the mine data, the uniaxial compressive strength of the test block needs to reach $1 \mathrm{MPa}$ or more to ensure safety. When the HC-tailing ratio is $1: 10$ to $1: 20$, the intensity of each group cannot reach $1 \mathrm{MPa}$. Under the premise of ensuring safety, the lower the content of $\mathrm{HC}$ is, the more economical it is, and the lower the mass concentration, the easier it is to transport. When the concentration is $70 \%$, the $\mathrm{HC}$ tailing ratio is $1: 8$ and can reach more than $1 \mathrm{MPa}$ in 28 days. Therefore, 70\% concentration was selected in LLGM.

The test blocks which HC-tailing ratio is $1: 8$ and the concentration is $70 \%$ were prepared. They were subjected to a bleeding test; bleeding rate was only $9.77 \%$. The results show that the filling material in the transport process does not appear segregation.

3.2. The OMF of Cement Quick-Setting Agent. After adding cement quick-setting agent, the coagulation cycle is shortened, so the recorded data is 1 day, 3 days, and 7 days. The rapid solidification test (concentration is $70 \%$ ) results were shown in Table 4.

The results show that the SCQA can speed up the solidification rate of the test blocks, but it does not increase the final strength. When the quick-setting agent was added, the test block which HC-tailings are 1:10 still cannot reach the safety requirement. While the HC-tailing ratio is $1: 6$ and $1: 8$, the addition of the quick-setting agent is $3 \%$; the effect is best. Solidification time decreased from 14 days and 28 days to 3 days and 7 days, respectively. When the SCQA content increases to $4 \%$ and $5 \%$, compressive strength of test blocks decreases. According to the test results and the requirements of LLGM mining method and goafs filling, it 


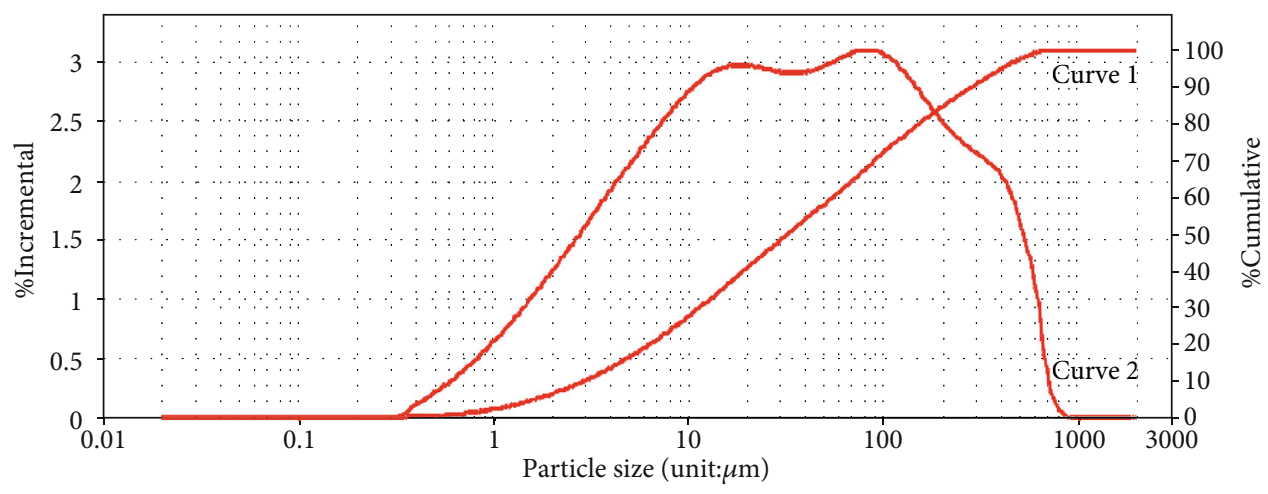

Figure 3: The particle size distributions of full tailings of LLGM (curve 1 is cumulative; curve 2 is incremental).

Table 1: Particle size characteristics of unclassified tailings.

\begin{tabular}{|c|c|c|c|c|c|c|}
\hline Particle size $(\mathrm{mm})$ & $(0.50,+\infty)$ & $(0.30,0.50)$ & $(0.10,0.30)$ & $(0.05,0.10)$ & $(0.01,0.05)$ & $(0.001,0.01)$ \\
\hline Proportion (\%) & 3.44 & 11.21 & 37.93 & 16.4 & 18.56 & 12.46 \\
\hline Characteristic diameter $(\mathrm{mm})$ & $d_{10}$ & $d_{50}$ & $d_{90}$ & & & \\
\hline Size $(\mu \mathrm{m})$ & 7.137 & 109.58 & 371.68 & & & \\
\hline
\end{tabular}

can be found that it is reasonable to add 3\% SCQA to the 70\% concentration filling slurry.

3.3. The OMF of Flocculants. The results of rapid subsidence tests were plotted in Figure 4.

The results show that the settling time of tailings is 39.8 min without the addition of flocculants. After flocculants are added, the settling rate of full tailings shows a rapid increase. Settling time reduces to 12 to 20 minutes. When flocculants reach to a certain value, there is no obvious change in increasing the amount of flocculants. Settling velocity and stable settling time can be intuitively obtained by Figure 3 . When the concentration of flocculants was $0.02 \%$, the addition of $2.4 \mathrm{~g}$ was the best. The amount of flocculation required for the tailings is $4.8 \mathrm{~g} / \mathrm{m}^{3}$. When the concentration of flocculants was $0.03 \%$, the addition of $1.2 \mathrm{~g}$ was the best. The amount of flocculation required for the tailings is $3.6 \mathrm{~g} / \mathrm{m}^{3}$. When the concentration of flocculants was $0.05 \%$, the addition of $1.2 \mathrm{~g}$ was the best. The amount of flocculation required for the tailings is $6 \mathrm{~g} / \mathrm{m}^{3}$. Finally, the $0.03 \%$ concentration flocculants and the addition of $1.2 \mathrm{~g}$ were selected in LLGM.

\section{Application in Linglong Gold Mine}

\subsection{Design of Cleaner Mining Method for Filling Mining Goafs by Tailings}

4.1.1. Filling Capacity and Service Life. According to the existing information provided by LLGM, the bulk density of tailings is $1.8 \mathrm{t} / \mathrm{m}^{3}$, and the ore density is $2.78 \mathrm{t} / \mathrm{m}^{3}$. The daily production of Jiuqu mining area is $4000 \mathrm{t}$ with cemented filling mining method, and daily treatment of tailings is $2679 \mathrm{t}$. The daily production of Xishan is $650 \mathrm{t}$, and daily treatment of tailings is $435 \mathrm{t}$. The daily increase in the amount of tailings is $1536 \mathrm{t}$. To reduce tailing accumulation and prevent surface subsidence, the capacity of new filling system needs to reach $1886 \mathrm{t}$ per day. The working hours are 10 hours per day; the concentration of filling slurry is $70 \%$; the capacity of new filling system requires to $133.72 \mathrm{~m}^{3} / \mathrm{h}$.

The total volume of goafs is about 5.2 million $\mathrm{m}^{3}$, and the daily filling volume is $1252.32 \mathrm{~m}^{3}(1886 \mathrm{t})$. The working periods are 330 days per year; therefore, the service life of filling system is 15.8 years.

4.1.2. Critical Velocity. The floating condition of the solid particles in the level sap flow generally uses the following empirical formula to calculate the critical velocity [54]:

$$
V_{C}=(g D)^{1 / 2}\left(\frac{\gamma_{p}-\gamma_{w}}{K \phi \gamma_{p} \gamma_{w} \lambda}\right)^{1 / 3}
$$

where $V_{C}$ is the critical velocity, $g$ is the acceleration of gravity as $9.8 \mathrm{~m} / \mathrm{s}^{2}, D$ is the pipe diameter, $\gamma_{p}$ is the slurry density, $\gamma_{w}$ is the water density as $1.0 \mathrm{t} / \mathrm{m}^{3}, K$ is the coefficient as 2.0 , and $\phi$ is the particle settlement resistance coefficient; $\phi=\left(\rho_{s}-\rho_{w}\right) \pi g d / 6 \rho_{w} v_{s}^{2}$, among them, $\rho_{s}$ is the particle density as $1.7902 \mathrm{t} / \mathrm{m}^{3}, d$ is the pipe diameter as the maximum $0.6 \mathrm{~mm}, \rho_{w}$ is the water density as $1.0 \mathrm{t} / \mathrm{m}^{3}$, and $V$ is the particle settlement velocity.

The concentration is $70 \%$; HC-tailing ratio is $1: 4,1: 6$, $1: 10$, and $1: 16$, respectively. The critical velocities were calculated according to equation (1), and the result is $2.02,2.25$, 2.38 , and 2.57 , respectively, in the range of 2.0 to $2.6 \mathrm{~m} / \mathrm{s}$. In practice, the minimum working flow rate of the filling slurry is $10 \%$ to $20 \%$ higher than the critical velocity. Considering the complicated and comprehensive factors of the goafs of LLGM, the critical velocity of full tailing is $3.0 \mathrm{~m} / \mathrm{s}$. 
TABLE 2: Chemical compositions of tailings and homemade cement (\%).

\begin{tabular}{lcccccccccccc}
\hline Compositions & $\mathrm{Mg}$ & $\mathrm{Al}$ & $\mathrm{K}$ & $\mathrm{Ca}$ & $\mathrm{Fe}$ & $\mathrm{Mn}$ & $\mathrm{Li}$ & $\mathrm{Si}$ & $\mathrm{Ba}$ & $\mathrm{Na}$ & $\mathrm{Other}$ \\
\hline Tailings & 4.87 & 6.10 & 2.05 & 25.1 & 1.77 & 0.51 & 0.10 & 11.2 & 0.08 & 0.97 & $<0.11$ \\
Homemade cement & 2.99 & 9.67 & 1.98 & 36.9 & 0.96 & 0.31 & 0.07 & 14.3 & 0.04 & 0.65 & $<0.08$ \\
\hline
\end{tabular}

TABLE 3: The average test results of compressive strength of test blocks (unit: MPa).

\begin{tabular}{lcccccccccccccc}
\hline $\begin{array}{l}\text { Curing periods } \\
\begin{array}{l}\text { Concentration } \\
\text { Ratio }\end{array}\end{array}$ & $65 \%$ & $67 \%$ & $70 \%$ & $75 \%$ & $65 \%$ & $67 \%$ & $70 \%$ & $75 \%$ & $65 \%$ & $67 \%$ & $70 \%$ & $75 \%$ \\
\hline $1: 4$ & 0.8561 & 1.0542 & 1.1758 & 1.3571 & 1.0759 & 1.3584 & 1.4603 & 1.8715 & 2.1338 & 2.4326 & 3.4154 & 4.7836 \\
$1: 6$ & 0.2850 & 0.3254 & 0.5547 & 0.9753 & 0.7712 & 0.7834 & 1.3412 & 1.4765 & 1.1551 & 1.3237 & 2.0276 & 3.1562 \\
$1: 8$ & 0.2051 & 0.3056 & 0.3718 & 0.5158 & 0.3931 & 0.5528 & 0.6905 & 0.8761 & 0.6534 & 0.7713 & 1.1337 & 2.0423 \\
$1: 10$ & 0.1928 & 0.2643 & 0.3463 & 0.3941 & 0.32065 & 0.4604 & 0.5351 & 0.4563 & 0.4716 & 0.4669 & 0.7852 & 0.9564 \\
$1: 12$ & 0.1709 & 0.2023 & 0.3015 & 0.3725 & 0.2527 & 0.3327 & 0.4018 & 0.3836 & 0.2857 & 0.5338 & 0.5719 & 0.5036 \\
$1: 16$ & 0.1063 & 0.1226 & 0.2087 & 0.2056 & 0.1351 & 0.1536 & 0.2102 & 0.2122 & 0.1542 & 0.1815 & 0.2128 & 0.2876 \\
$1: 20$ & 0.0821 & 0.0936 & 0.0826 & 0.0974 & 0.1012 & 0.1047 & 0.0826 & 0.1263 & 0.1128 & 0.1273 & 0.1282 & 0.1514 \\
\hline
\end{tabular}

TABLE 4: The average compressive strength of the test blocks (unit: $\mathrm{MPa}$ ).

\begin{tabular}{lcccc}
\hline $\begin{array}{l}\text { HC-tailing } \\
\text { ratio }\end{array}$ & $\begin{array}{c}\text { 1 d (unit: } \\
\mathrm{MPa})\end{array}$ & $\begin{array}{c}3 \mathrm{~d} \text { (unit: } \\
\mathrm{MPa})\end{array}$ & $\begin{array}{c}7 \mathrm{~d} \text { (unit: } \\
\mathrm{MPa})\end{array}$ & $\begin{array}{c}\text { Quick-setting } \\
\text { agent }(\%)\end{array}$ \\
\hline \multirow{3}{*}{$1: 6$} & 0.633 & 1.265 & 1.969 & $3 \%$ \\
& 0.623 & 1.186 & 1.733 & $4 \%$ \\
& 0.613 & 1.126 & 1.571 & $5 \%$ \\
\hline \multirow{3}{*}{$1: 8$} & 0.58 & 0.825 & 1.288 & $3 \%$ \\
& 0.554 & 0.729 & 1.137 & $4 \%$ \\
& 0.485 & 0.777 & 1.088 & $5 \%$ \\
$1: 10$ & 0.345 & 0.633 & 0.856 & $3 \%$ \\
& 0.313 & 0.637 & 0.812 & $4 \%$ \\
& 0.293 & 0.593 & 0.728 & $5 \%$ \\
\hline
\end{tabular}

According to the previous calculation, the capacity of new filling system requires to $143.72 \mathrm{~m}^{3} / \mathrm{h}$; the critical velocity of full tailing is $3.0 \mathrm{~m} / \mathrm{s}$. The diameter of filling pipe is calculated according to the data, and the result is greater than $90 \mathrm{~mm}$. Finally, $100 \mathrm{~mm}$ diameter pipes were selected as the filling pipes.

4.1.3. Pipeline Resistance. The Jinchuan formula is applicable to the pipe with a diameter of $100 \mathrm{~mm}$, and the error is small. Therefore, Jinchuan formula was adopted to calculate the pipeline resistance in this study [55].

$$
i_{j}=1.125 i_{0}\left\{1+108 m_{t}^{3.96}\left[\frac{g D\left(\gamma_{g}-1\right)}{v^{2} \sqrt{C_{x}}}\right]^{1.12}\right\},
$$

where $i_{j}$ is the filling Slurry hydraulic gradient, $i_{0}$ is the water hydraulic gradient, $v$ is the flow speed of slurry, $C_{x}$ is the particle settlement resistance coefficient as 0.997, $\gamma_{g}$ is the solid material density, and $m_{t}$ is the mass concentration of filling slurry.

$$
i_{0}=\lambda \frac{L}{D} \times \frac{v^{2}}{2 g}
$$

where $\lambda$ is the friction coefficient. According to the Nicolas formula multiplied by the coefficient $K$ :

$$
\lambda=\frac{K_{1} \bullet K_{2}}{(2 \lg (D / 2 \Delta)+1.74)^{2}},
$$

where $K_{1}$ is the Pipeline laying coefficient as $1.12, K_{2}$ is the pipe joint coefficient as $1.15, g$ is the acceleration of gravity, $D$ is the pipe diameter, and $\Delta$ is the absolute roughness of pipe as $0.01 \mathrm{~mm}$.

The flow resistance was calculated according to the equation, and the result is $2.269 \mathrm{KPa} / \mathrm{m}$; therefore, the pipeline pressure in all the middle sections of LLGM is available. According to the design of the filling pipe network, the pipe resistance distribution of goafs filling pipe networks is shown in Figure 5(b).

4.1.4. Wall Thickness. The filling pipe wall thickness is calculated by allowable strength of the material. The tension of filling pipe wall is [55]:

$$
P=\iint \delta_{n} \frac{d}{2} \sin a l=d l \delta_{n}
$$

where $d$ is the filling pipe diameter, $\delta$ is the pipe wall thickness, and $\mathrm{m}^{3}$ is the filling pipe pressure.

The inner wall sectional area of the filling pipe is:

$$
S=2 t \times \Delta l,
$$




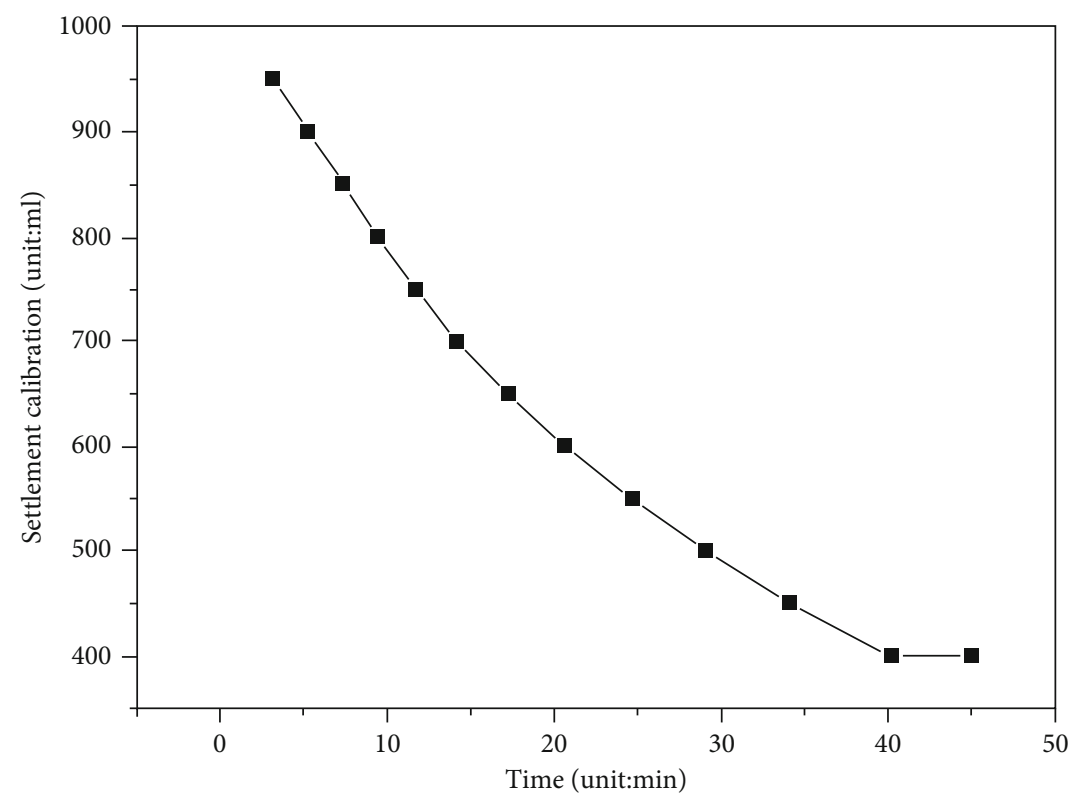

-ם- Settlement curve

(a)

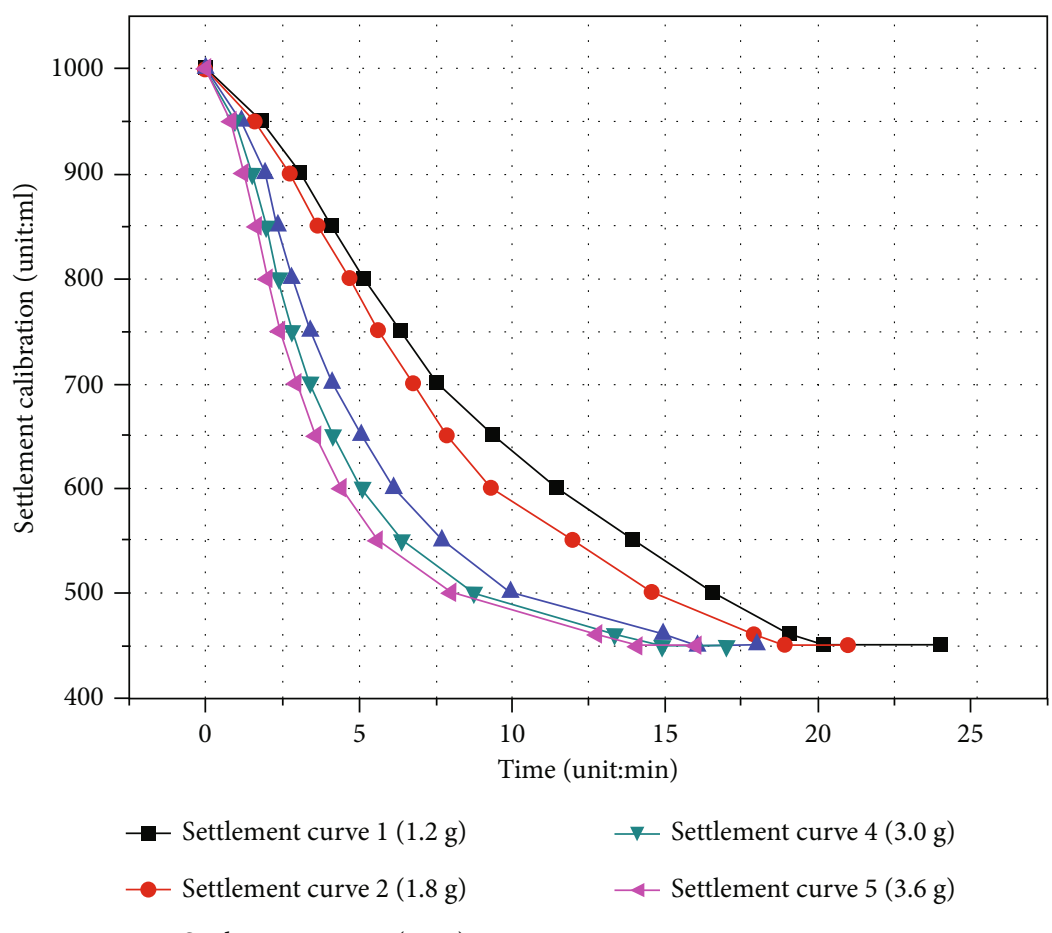

$\leftarrow$ Settlement curve 3 (2.4 g)

(b)

Figure 4: Continued. 


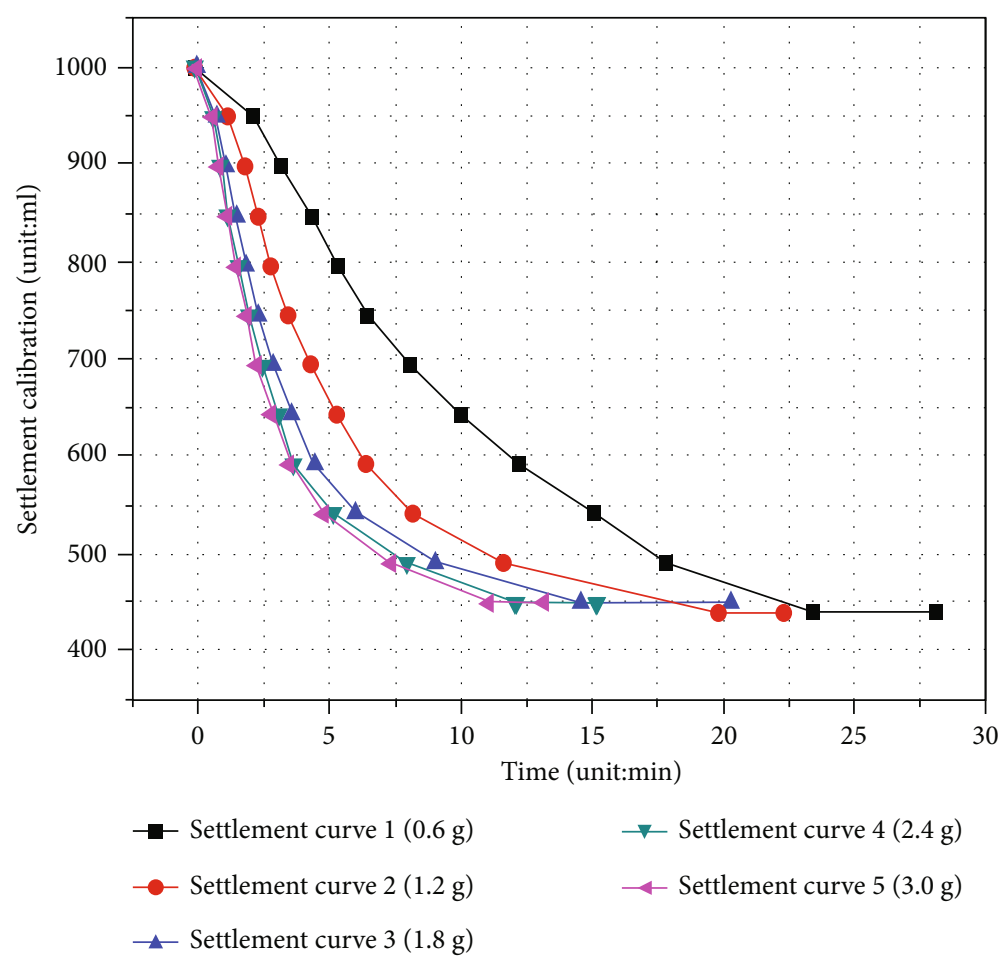

(c)

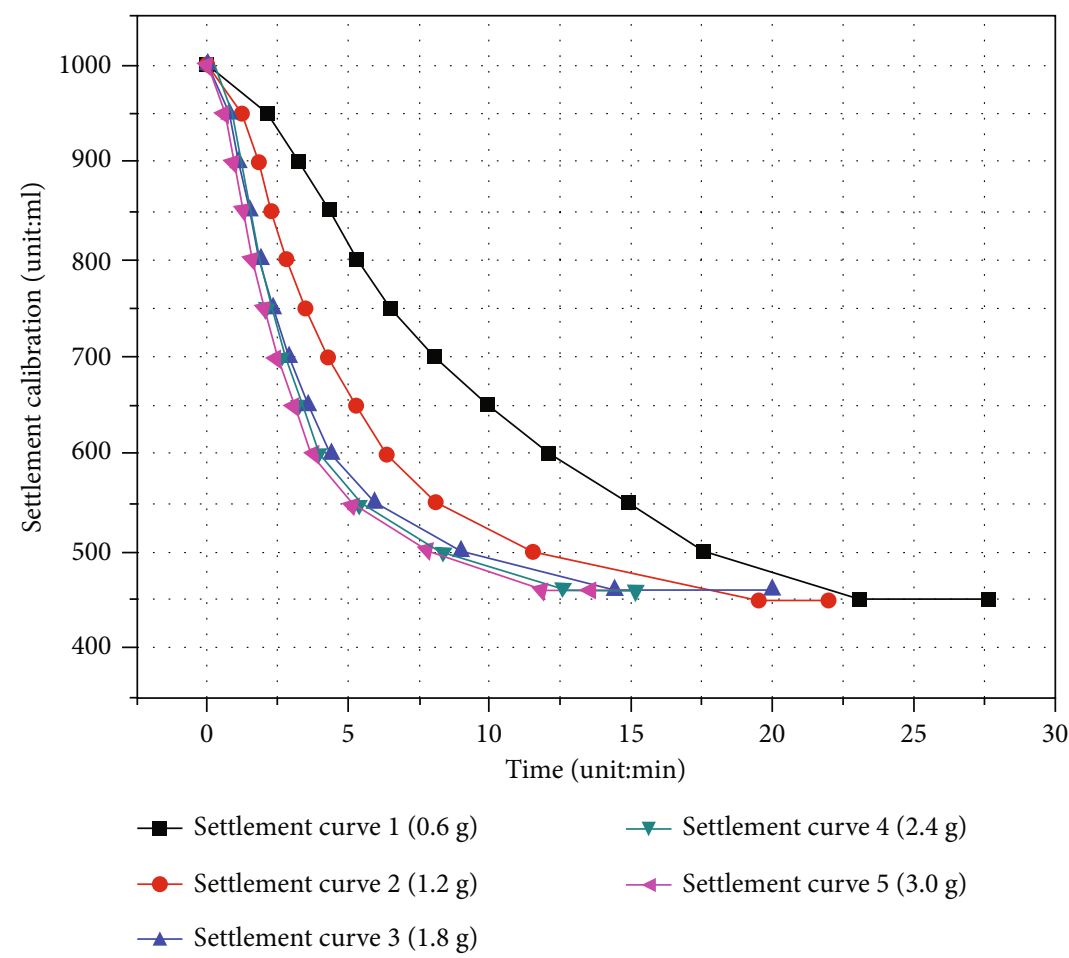

(d)

Figure 4: The settlement curve of tailings at different time: (a) the flocculant concentration was 0 , (b) the flocculant concentration was $0.2 \mathrm{~g} / 1000 \mathrm{ml}$, (c) the flocculant concentration was $0.3 \mathrm{~g} / 1000 \mathrm{ml}$, and (d) the flocculant concentration was $0.5 \mathrm{~g} / 1000 \mathrm{ml}$.

where $S$ is the inner wall sectional area, $t$ is the pipe wall thickness, and $\Delta l$ is the unit length of pipe.

The filling pipe in the middle of the roadway is used for a long time, so the seamless steel pipe is used. When the pipe is close to the empty zone, the PVC material pipe is used for the convenience of folding and filling. Through a large number of calculations, the $100 \mathrm{~mm}$ diameter of seamless steel pipes was selected, and the wall thickness was $5.0 \mathrm{~mm}$. The 


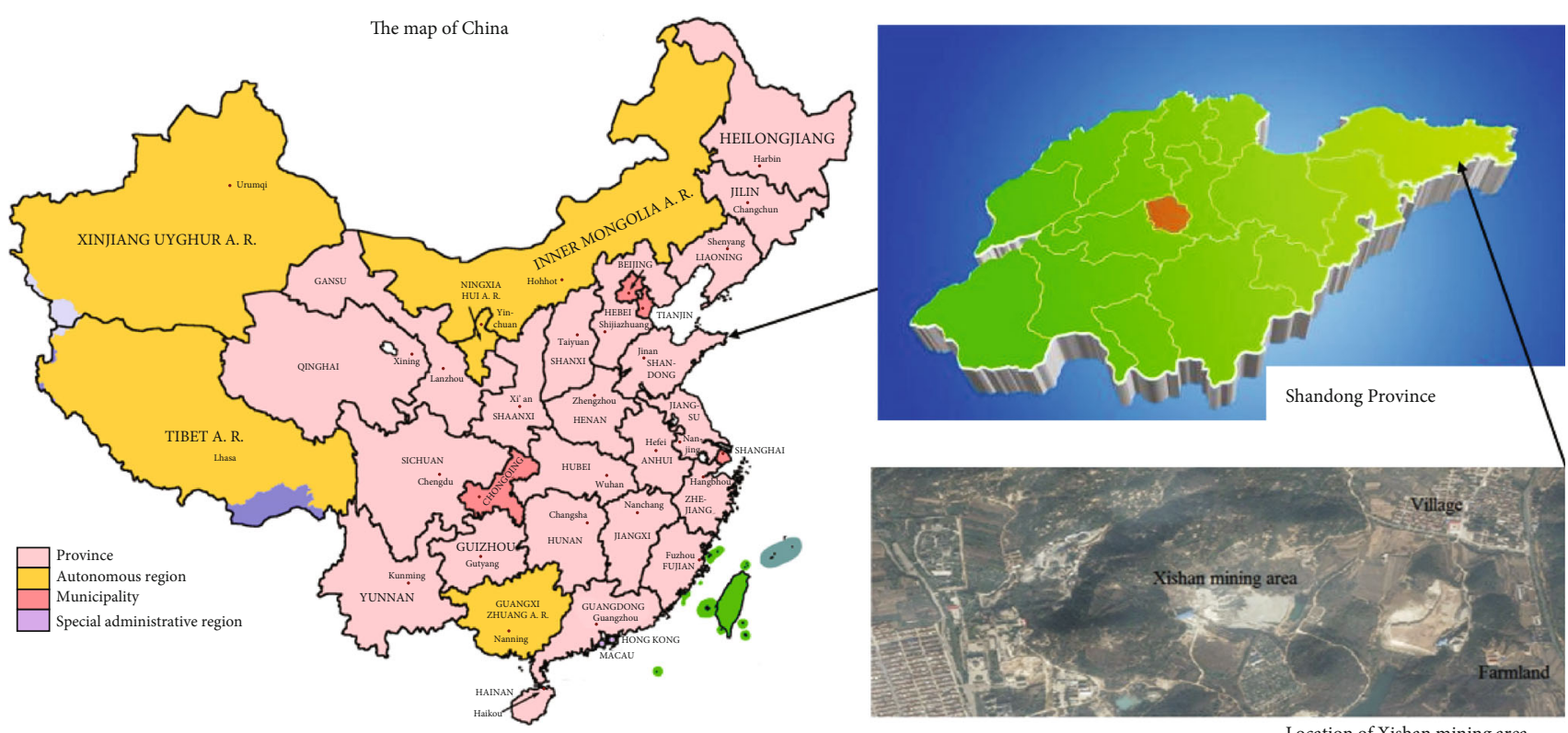

(a)

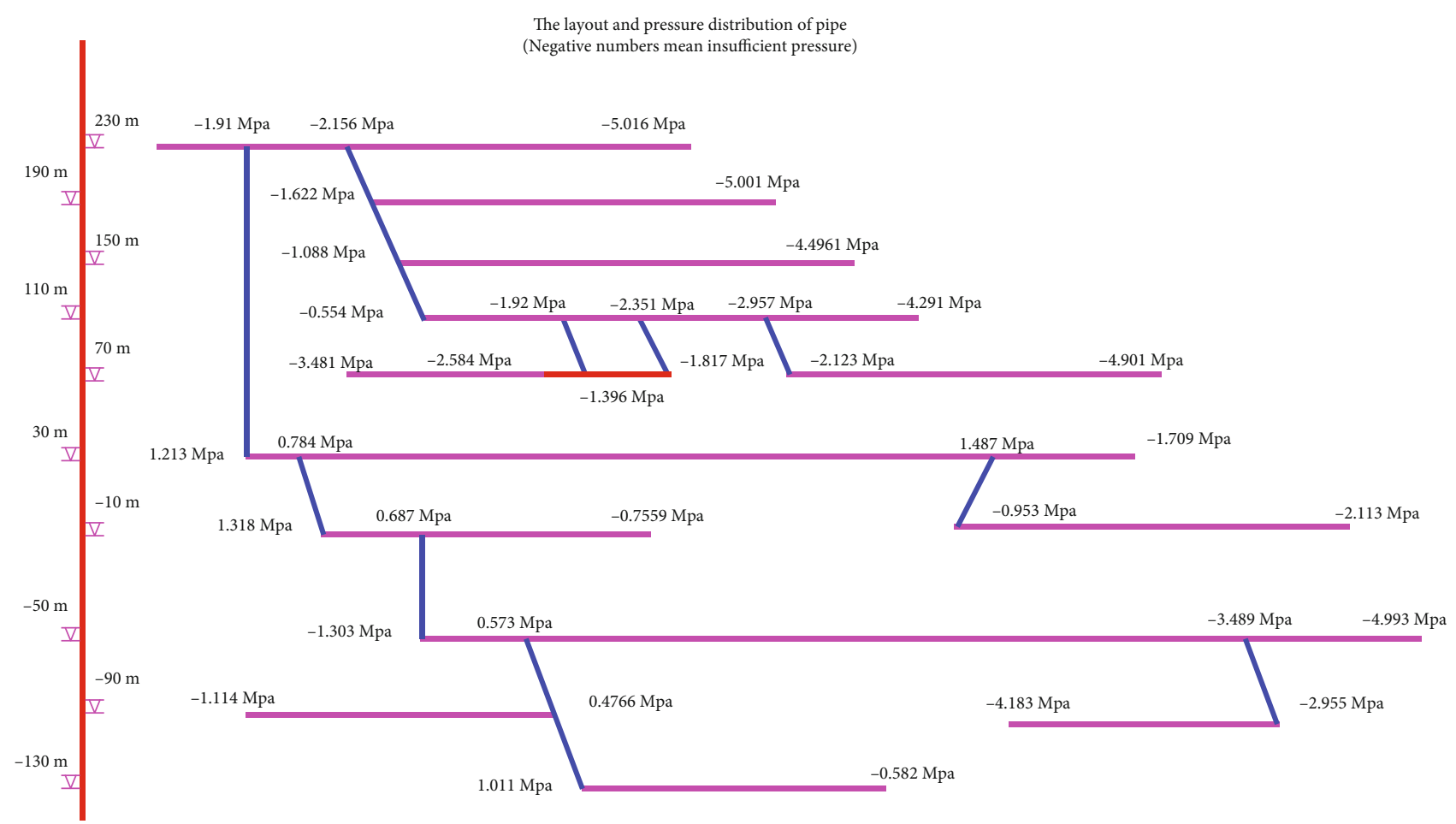

(b)

FIGURE 5: (a) The geographical location of the Xishan mining area and (b) the layout and pressure distribution of pipe network of Xishan mining area.

$90 \mathrm{~mm}$ diameter PVC plastic pipes with a thickness of $10 \mathrm{~mm}$ which can meet the technical requirements of pressure $4 \mathrm{MPa}$ were selected.

4.1.5. Filling Pipe Network of Xishan Mining Area. As the resources in the shallow areas are declining, the mines have entered the state of deep resource exploitation successively.
But the digging deepens with the pressure appears more and more obvious. Therefore, filling method is necessary in deep mining. First, the filling pipe network of the Xishan Mining Area was designed. The construction of filling system of Xishan mining area should not only consider the production of mining area filling but also the deposed and old laneway filling. The geographical location of the Xishan mining 


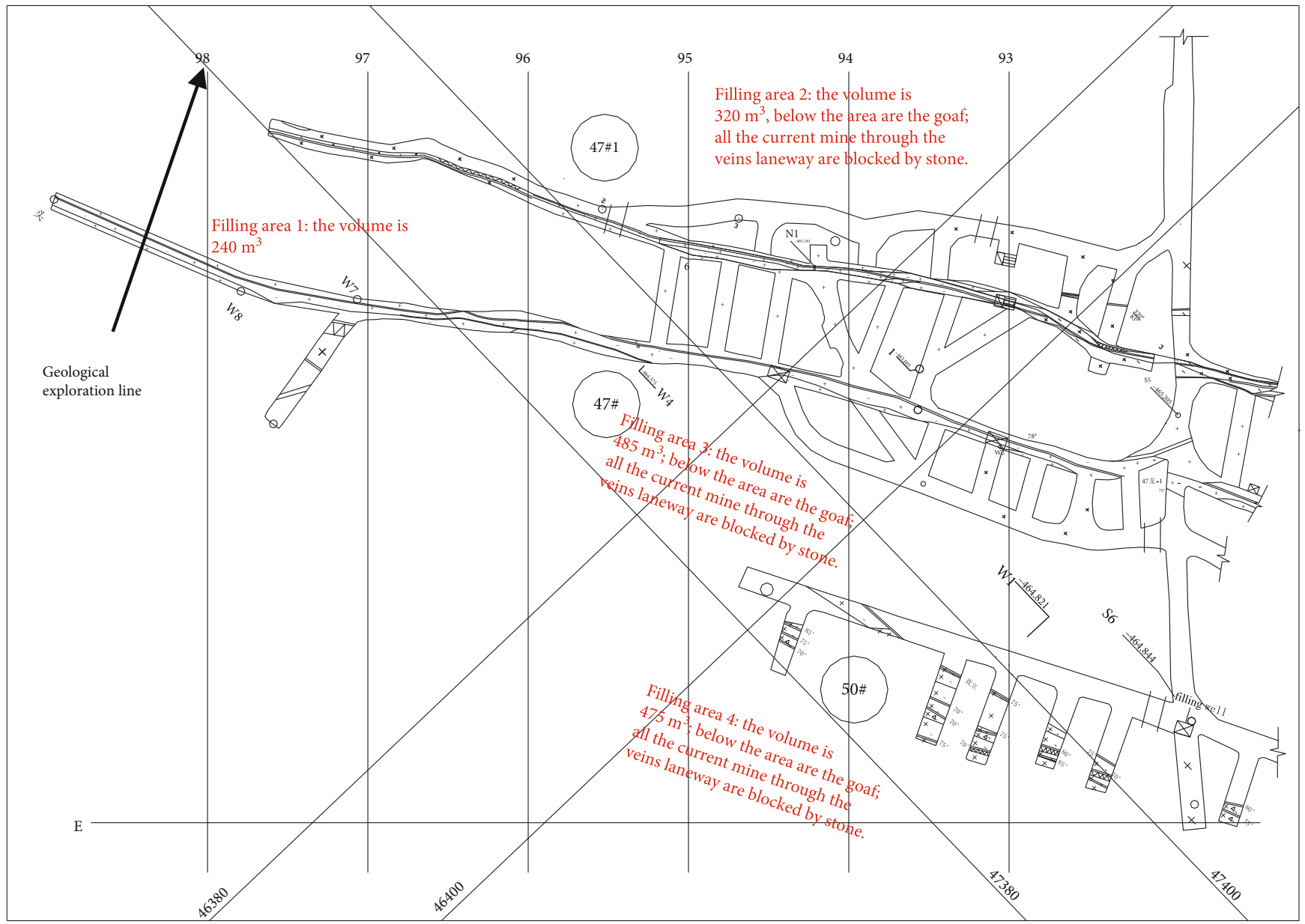

FIGURE 6: Deposed roadway filling experiment site selection.

area was shown in Figure 5(a); the pressure distribution of pipe network of Xishan mining area was plotted in Figure 5(b).

In the natural state, the pressure at each location is shown in Figure 5(a); the maximum insufficient pressure is $5.016 \mathrm{MPa}$. Filling times line of the filling pipe network was calculated; the farthest filling distance of mining area is $4091 \mathrm{~m}$; the maximum vertical drop is $390 \mathrm{~m}$. The filling lines of $190 \mathrm{~m}, 150 \mathrm{~m}, 110 \mathrm{~m}, 70 \mathrm{~m}, 30 \mathrm{~m},-10 \mathrm{~m},-50 \mathrm{~m},-90 \mathrm{~m}$, and $-130 \mathrm{~m}$ and middle parts were $62,32,23,21,11,10,13,12$, and 7, respectively. Because of the high filling line, it is necessary to add a booster pump during transportation.

4.1.6. Filling System. Filling station to the adit is about 30$50 \mathrm{~m}$, due to the high pressure, difference is insufficient to deliver the filling slurry to 230 level adit, and therefore, a filling pump is necessary. When slurry is transported to the adit, filling pump need to overcome resistance is $5.13 \mathrm{MPa}$.

Constructing two sets of filling system, a single set of filling capacity is $80 \mathrm{~m}^{3} / \mathrm{h}$.

LLGM filling system main facilities and equipment are as follows: 4 tailing bin, 4 cement bin, 4 sets of linkage with wind and water activated making pulp device, 4 sets of warehouse with DN150 cast stone wear electrical ball valve, 4 sets of $1800 \times 1800$ double impeller high concentration mixing drum with motor $30 \mathrm{kw}, 4$ sets of $3300 \times$ DN200 doublescrew feeder with flow $25 \mathrm{~m}^{3} / \mathrm{h}$ and $7.5 \mathrm{kw}$ motor frequency control, 4 sets of SIW $\varphi 125 \times 2.5 \mathrm{~m}$ double-screw feeder, flow $2 \sim 5 \mathrm{~m}^{3} / \mathrm{h}, 1.5 \mathrm{kw}$ motor, frequency control, 4 sets of water pump with flow more than $30 \mathrm{~m}^{3} / \mathrm{h}, 2$ sets of $2 \mathrm{P}$ mud pump, 4 sets of cement warehouse dust collector, and 2 sets of plunger mud pump.

Filling system investment in civil construction costs $7,800,000$ Yuan, filling system equipment costs 11,200,000 Yuan (each plunger mud pump costs 800,000 Yuan), pipeline costs 780,000 Yuan, and filling system investment totaling costs 19,780,000 Yuan.

4.2. Application Experiments and Economic Analysis. The conclusions obtained from the laboratory may not be applicable to the mine because the geological conditions of the mine are complex and changeable, and the mining methods are not exactly the same. Therefore, application experiment was carried out. Drainage technique is the key of the backfill process; the dehydration technology and dewatering equipment are described in the study for this problem.

4.2.1. Experiment Site. The application experiment was carried out in both the laneway and the goafs for getting the effect in practice. The deposed and old laneway filling was 


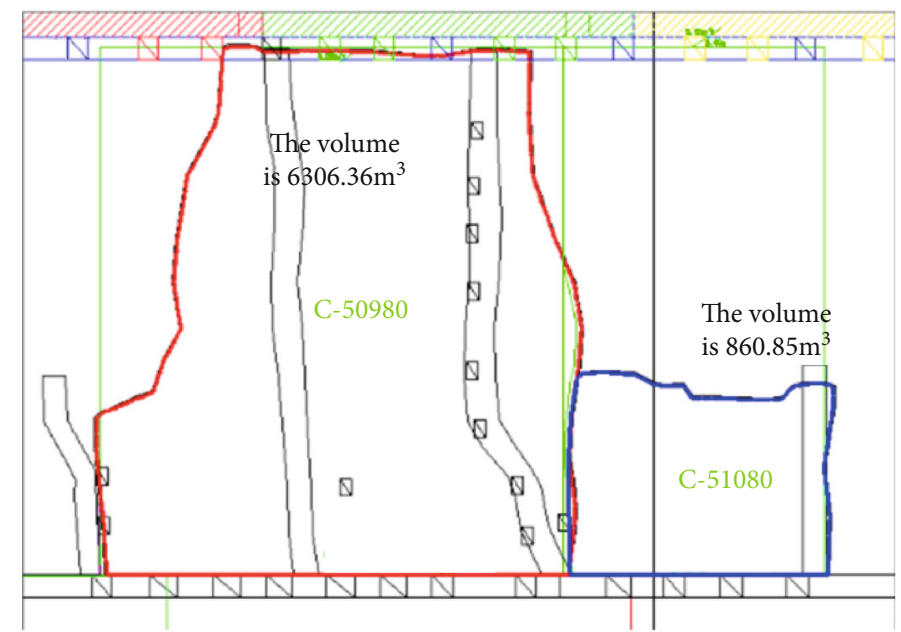

(a)

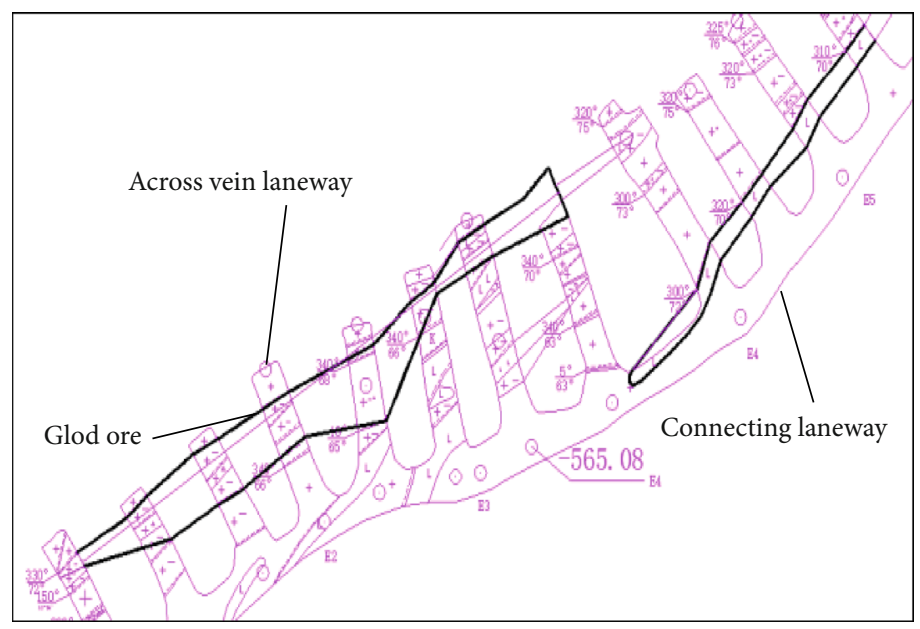

(b)

Figure 7: (a) The vertical projection map of goafs and (b) the floor plan of $-565 \mathrm{~m}$.

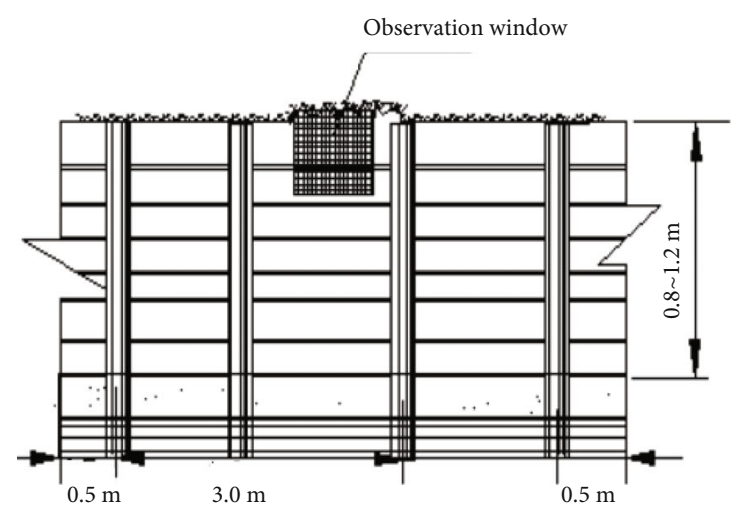

(a)
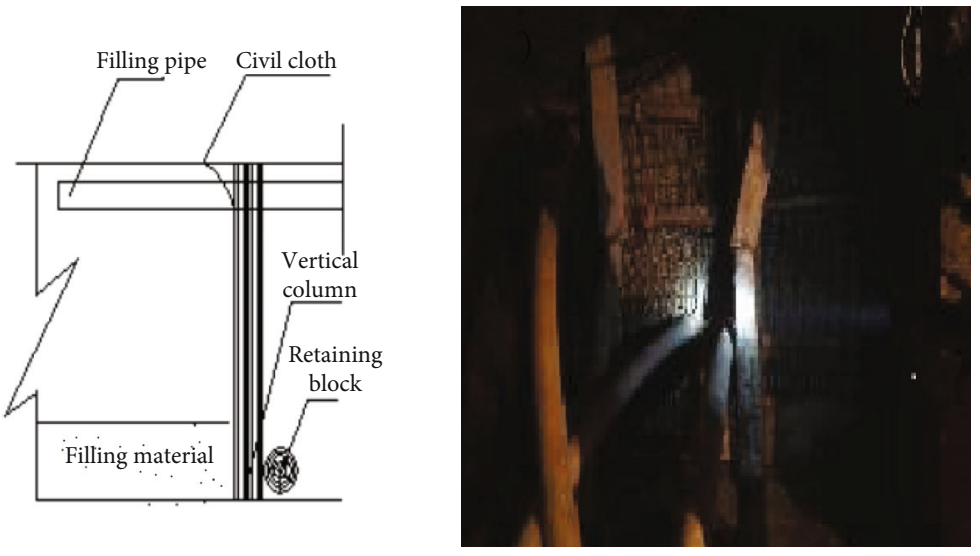

(b)

FIGURE 8: (a) The structure of retaining wall and (b) the hanging recycled filling retaining wall.

selected in the $-70 \mathrm{~m}$ middle part section 47 and 50 veins (Figure 6), and the goafs filling was selected in the C-50980 goafs and C-51080 goafs (Figure 7).
4.2.2. Filling Retaining Wall. The structure of retaining wall in Figure 8(a), it consists of four parts: observation window, civil cloth, vertical column, and ground retaining blocks. 


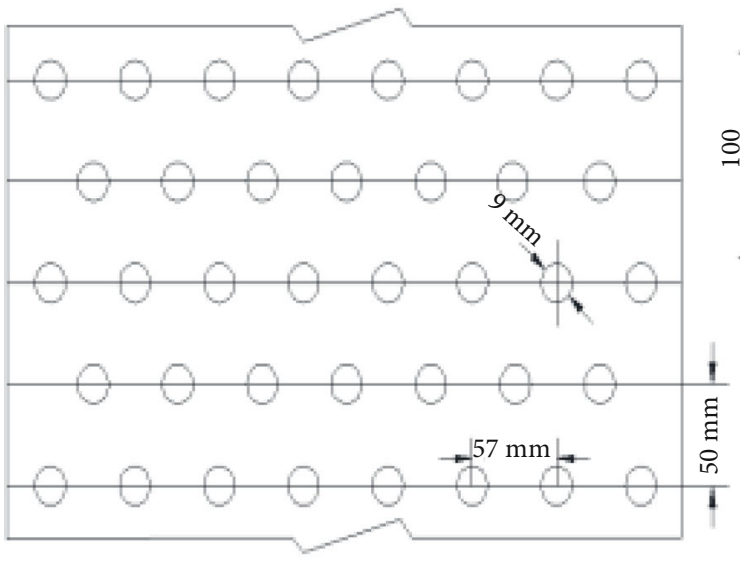

Plastic dewatering hole layout (expand)

1-Plastic bellows

2-Filter cloth

3-Wire rope

4-Tower joints
5-Tube clamp

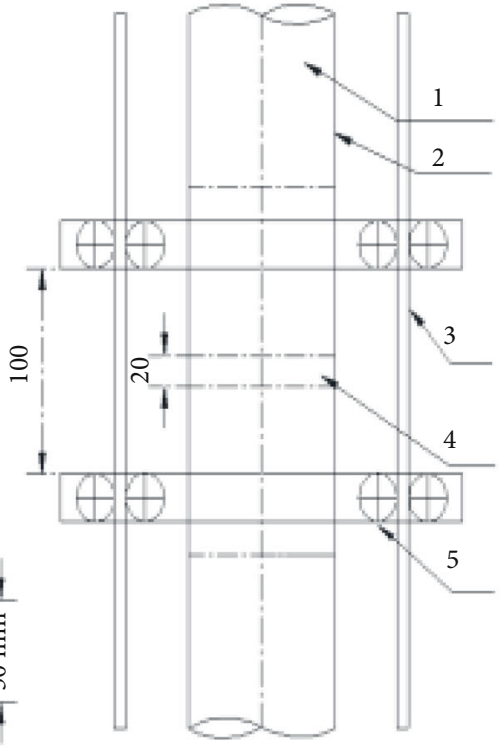

Dehydration pipe joint structure (a)

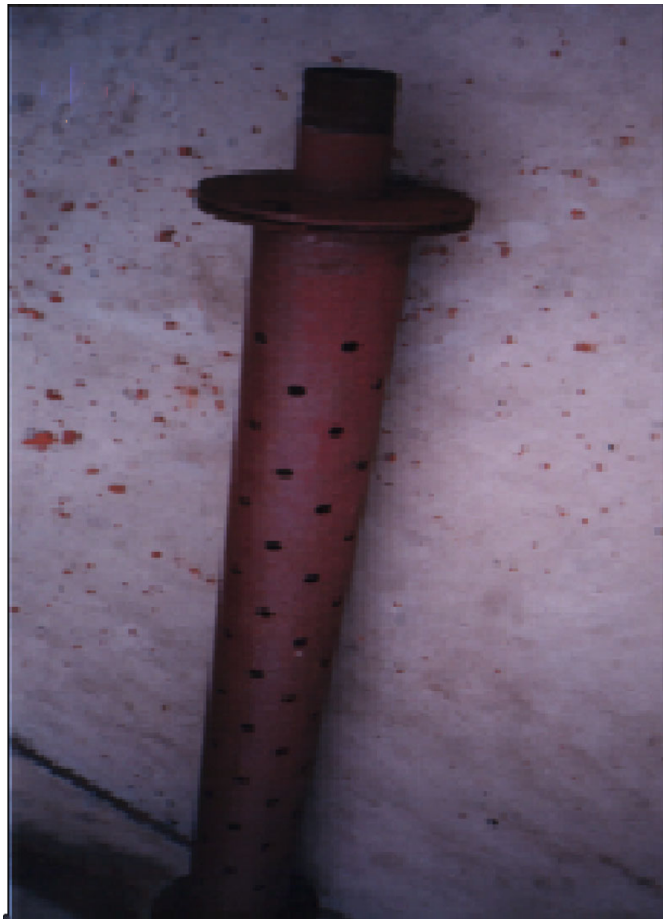

(b)

Figure 9: (a) The structure of drainage pipes for internal drainage and (b) the equipment of external drainage.

The main material of the retaining wall is wood, the steel pipe was used as a fixed, and the outer layer is wrapped with a wire mesh of $8 \mathrm{~mm}$ in diameter. The construction of hanging recycled filling retaining wall is shown in Figure 8(b).
4.2.3. Internal and External Drainage of the Stope. The layout of drainage pipes for internal drainage is shown in Figure 9(a); the drainage pipe diameter is $100 \mathrm{~mm}$, and the wall thickness is about $10 \mathrm{~mm}$. In the drainage pipes, 


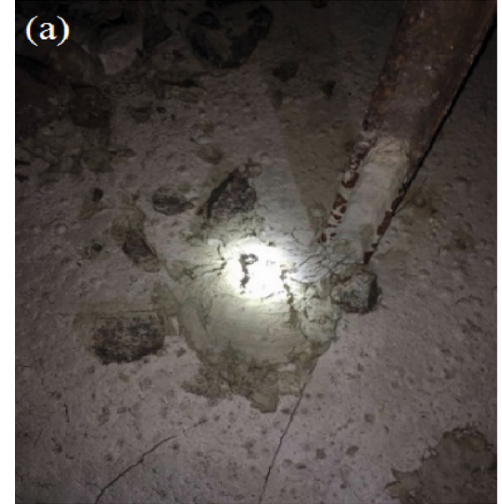

(a)

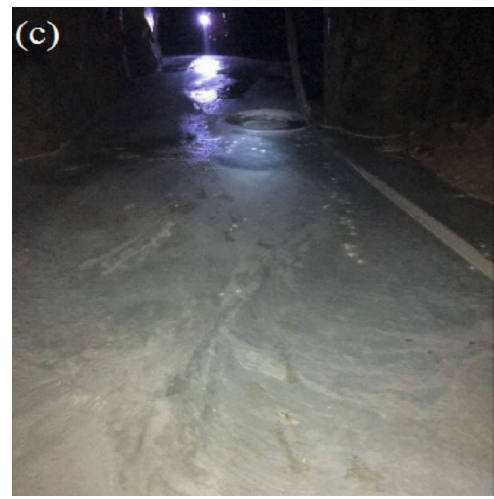

(c)

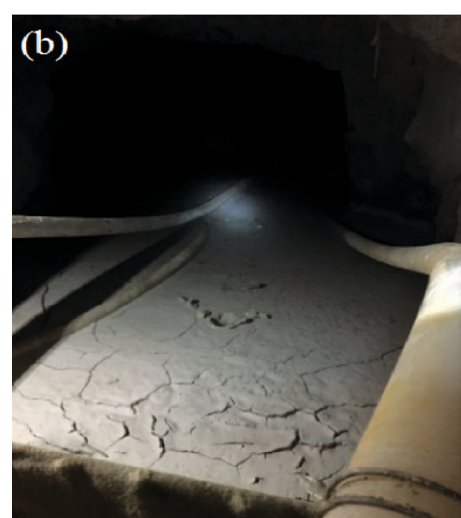

(b)

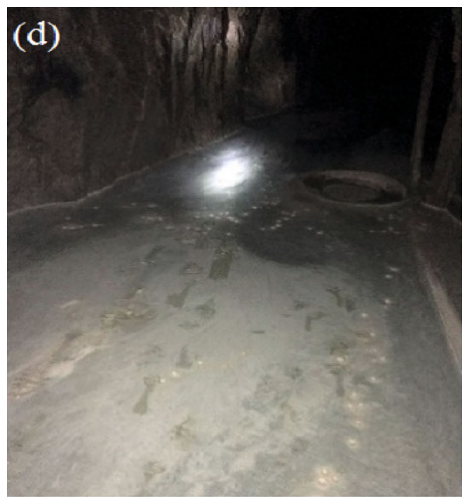

(d)

Figure 10: $(a, b)$ The effect of laneway backfilling. (c, d) The effect of goafs backfilling.

TABLE 5: The cost of backfill tailings.

\begin{tabular}{|c|c|c|c|c|}
\hline Serial number & Project & Dosage & Unit price & Filling costs $\left(\right.$ Yuan $\left./ \mathrm{m}^{3}\right)$ \\
\hline I & Homemade cement & $0.264 \mathrm{t} / \mathrm{m}^{3}$ & 290 Yuan/t & 7.66 \\
\hline II & Auxiliary materials & & & \\
\hline 1 & Pipe & $2.5 e-3 \mathrm{~m} / \mathrm{m}^{3}$ & 200 Yuan/m & 0.5 \\
\hline 2 & Filling retaining wall & $1.7 e-2 \mathrm{~m}^{3} / \mathrm{m}^{3}$ & 105 Yuan $/ \mathrm{m}^{3}$ & 1.80 \\
\hline 3 & Flocculants & $3.6 \mathrm{~g} / \mathrm{m}^{3}$ & 0.05 Yuan/g & 0.18 \\
\hline 4 & Quick-setting agent & $7.4 \mathrm{~g} / \mathrm{m}^{3}$ & $7.2 e-4$ Yuan $/ \mathrm{m}^{3}$ & $5.3 e-3$ \\
\hline III & Water & $0.7 \mathrm{t} / \mathrm{m}^{3}$ & 2.00 Yuan/t & 1.40 \\
\hline IV & Electricity & 0.99 degree $/ \mathrm{m}^{3}$ & 0.65 Yuan/degree & 6.45 \\
\hline $\mathrm{V}$ & Productive wages & & & 12.05 \\
\hline \multirow[t]{2}{*}{ VI } & Depreciation funds & & & 0.87 \\
\hline & Summation & & & 30.92 \\
\hline
\end{tabular}

the diameter is $9 \mathrm{~mm}$, and the holespacing is $57 \mathrm{~mm}$ with $50 \mathrm{~mm}$ row distance. Because sometimes a drainage pipe is not long enough, it needs a joint extension. Plastic bellows outsourcing filter cloth which specifications is 240 meshes and then in the filter cloth outsourcing layer of sack cloth.

4.2.4. Backfill Effect. During the application experiment, the effluent flows out through the filling retaining wall and gap, the production of the filling the seepage can be seen, and the effluent water settles formed a very dense layer of mud (Figure 10). It is indicated that the backfill of tailings is in good condition, and the application experiment has achieved good results.

4.2.5. Backfill Cost. In application experiment goafs and deposed laneway filled with $7014 \mathrm{~m}^{3}$ tailings, the total cost was 217,000 Yuan; filling costs was $30.92 \mathrm{Yuan} / \mathrm{m}^{3}$. The detailed price list is shown in Table 5 . 


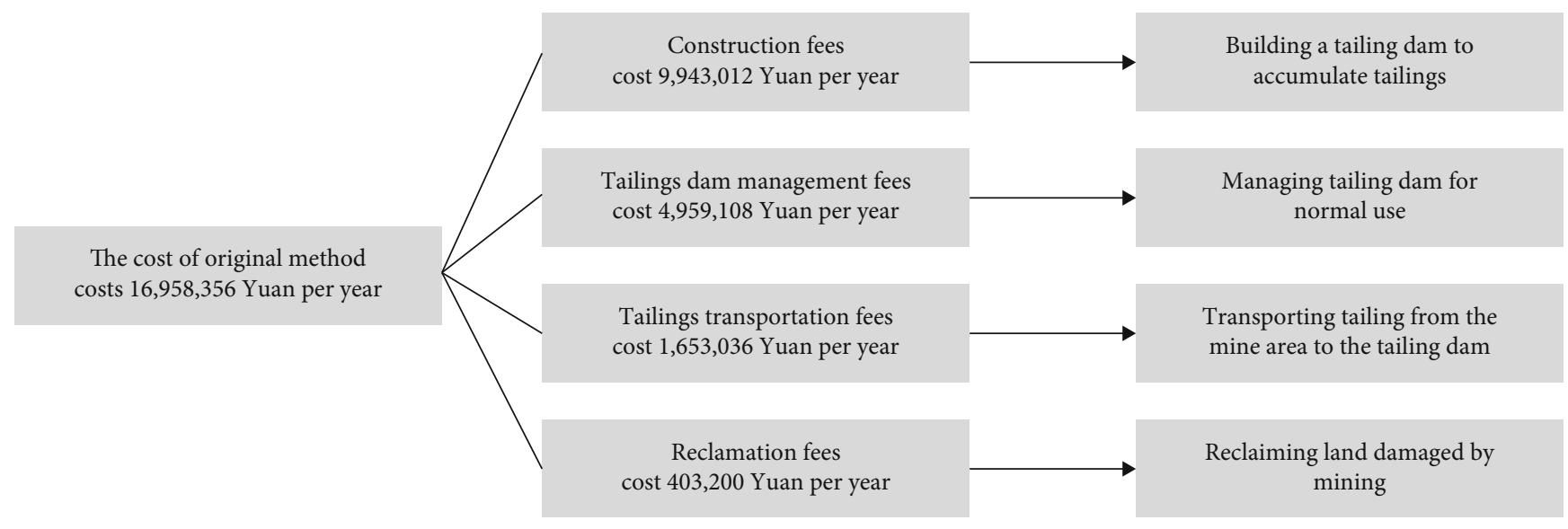

(a)

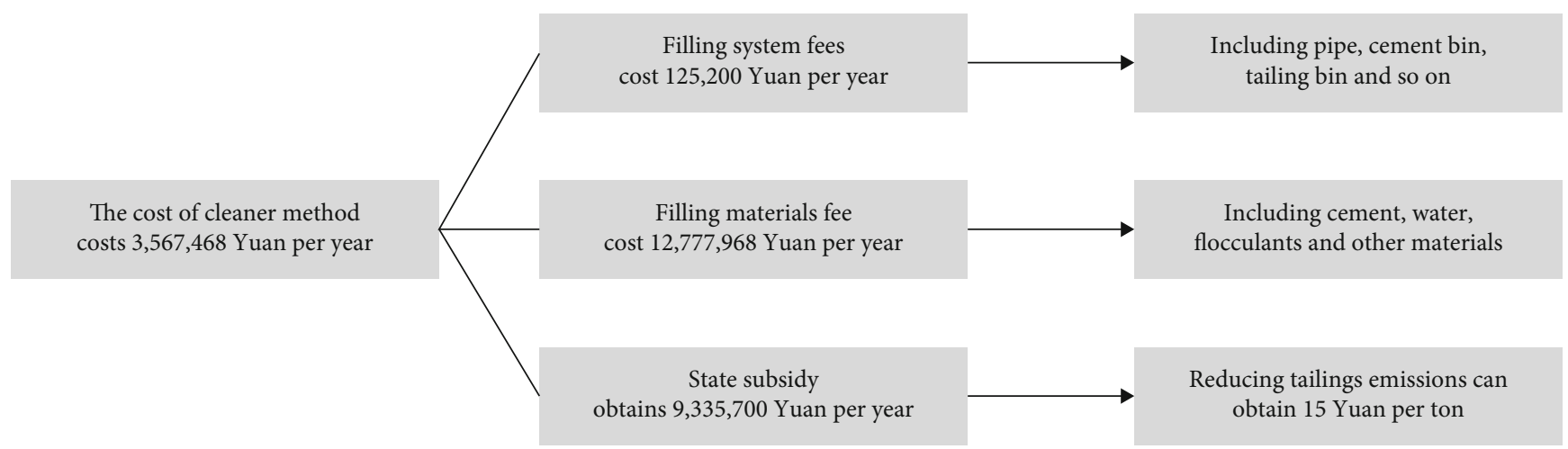

(b)

Figure 11: (a) The cost of original method and (b) the cost of cleaner method.

4.3. Economic Benefit. The cleaner mining method was compared with the original method. The cost of using the original method is construction fees, tailing dam management fees, transportation fees, and reclamation fees [56]. The new filling system can fill the amount of $1886 \mathrm{t}\left(1252.3 \mathrm{~m}^{3}\right)$ tailings to the empty area per day. The working days are 330 per year. The amounts of tailings processed each year are $413,259 \mathrm{~m}^{3}$. According to the experience of tailing construction in different regions of China, the unit price of tailing construction fees is $24.06 \mathrm{Yuan} / \mathrm{m}^{3}$, the unit price of tailing management fees is $12 \mathrm{Yuan} / \mathrm{m}^{3}$, the unit price of tailing transportation fees is $4 \mathrm{Yuan} / \mathrm{m}^{3}$, and the unit price of tailing dam reclamation fees is $2.24 \mathrm{Yuan} / \mathrm{m}^{2}$; the annual area of reclamation is $180,000 \mathrm{~m}^{2}$ per year. The final fees are shown in Figure 11(a).

The cost of using the cleaner mining method is filling system projects investment budget and filling fees. Filling system project investment budget is 19,780,000 Yuan (the service life is 15.8years, annual depreciation of 1,252,000 Yuan), and the unit price of filling fees is $30.92 \mathrm{Yuan} / \mathrm{m}^{3}$. At the same time, reduce tailing emissions can obtain the state subsidy 15 Yuan/t. The final fees are shown in Figure 11(b).

Finally, the new mining method can bring 13,390,888 Yuan economic benefits per year; it also prevented surface subsidence and reduced tailing accumulation. The ecological environmental benefits to humanity are inestimable.

\section{Conclusions}

Huge amounts of tailings are stored on the surface land, resulting land acidifications and poisons. The goafs can lead to stope instability and ground subsidence, causing damage to residential buildings and infrastructures. This study proposed a cleaner mining method for filling mining goafs by tailings in LLGM, located in Shandong province, China. The mechanical performance of the CTB was related to the slurry concentration and $\mathrm{HC} /$ tailing ratio. The compressive strength tests showed that $\mathrm{C}$ material was the decisive factor of the cemented filling. In order to realize continuous rapid filling tailings, adding the cements quick-setting agent and flocculants was necessary. The result of tests showed that $70 \%$ slurry concentration, 1:8 HC/tailing ratio, 3\% cement quick-setting, and $0.03 \%$ concentration flocculants were reasonable mix proportion.

The filling system which can service 15.8 years for LLGM was designed. Then, application experiment was a success in LLGM. Finally, the economic benefits of the cleaner mining method and the old method were compared. The cleaner mining method costs 13,390,888 Yuan less than the old method per year. But when analyzing the related physical parameters of tailings, the tailing parameters are regarded as deterministic parameters. This may affect the subsequent test results. In future research, the uncertainty of the 
parameters could be taken into consideration. Overall, the cleaner mining method is a greener and economically productive way to be widely used in the future. When analyzing the related physical parameters of tailings, the tailing parameters are regarded as deterministic parameters. This may affect the subsequent test results. In future research, the uncertainty of the parameters could be taken into consideration.

\section{Abbreviations}

CTBB: Cemented tailing backfilling

LLGM: Linglong gold mine

CPC: The Communist Party of China

HC: Homemade cement

OMF: Optimum mix formulation

SCQA: Sodiumaluminate cement quick-setting agent

$V_{C}$ : Critical velocity

g: Acceleration of gravity

D: $\quad$ Pipe diameter

$\gamma_{p}: \quad$ Slurry density

$\gamma_{w}: \quad$ Water density

$\phi$ : $\quad$ Particle settlement resistance coefficient

$i_{j}: \quad$ Filling slurry hydraulic gradient

$i_{0}$ : Water hydraulic gradient

$v$ : $\quad$ Flow speed of slurry

$C_{x}$ : $\quad$ Particle settlement resistance coefficient

$m_{t}$ : Mass concentration of filling slurry

$\lambda: \quad$ Friction coefficient

$\delta: \quad$ Pipe wall thickness

$\mathrm{m}^{3}$ : $\quad$ Filling pipe pressure

$\Delta l$ : Unit length of pipe.

\section{Data Availability}

The data used to support the findings of the study can be available from the corresponding author.

\section{Conflicts of Interest}

The authors declare that they have no known competing financial interests or personal relationships that could have appeared to influence the work reported in this paper.

\section{Acknowledgments}

The authors wish to acknowledge financial support from the National Natural Science Foundation of China (No. 51774327, No. 51974359, and No. 51674288).

\section{References}

[1] M. Benzaazoua, B. Bussière, I. Demers, M. Aubertin, É. Fried, and A. Blier, "Integrated mine tailings management by combining environmental desulphurization and cemented paste backfill: application to mine Doyon, Quebec, Canada," Minerals Engineering, vol. 21, no. 4, pp. 330-340, 2008.

[2] R. Showstack, "Mineral expert discusses global scramble for natural resources," Eos Transactions American Geophysical Union, vol. 94, no. 47, pp. 434-434, 2013.
[3] X. Song, J. B. Pettersen, K. B. Pedersen, and S. Røberg, "Comparative life cycle assessment of tailings management and energy scenarios for a copper ore mine: a case study in Northern Norway," Journal of Cleaner Production, vol. 164, pp. 892904, 2017.

[4] A. Tisserant and S. Pauliuk, "Matching global cobalt demand under different scenarios for co-production and mining attractiveness," Journal of Economic Structures, vol. 5, no. 1, p. 4, 2016.

[5] L. Dong, X. Tong, X. Li, J. Zhou, S. Wang, and B. Liu, "Some developments and new insights of environmental problems and deep mining strategy for cleaner production in mines," Journal of Cleaner Production, vol. 210, pp. 1562-1578, 2019.

[6] G. Fellet, L. Marchiol, G. Delle Vedove, and A. Peressotti, "Application of biochar on mine tailings: effects and perspectives for land reclamation," Chemosphere, vol. 83, no. 9, pp. 1262-1267, 2011.

[7] L. Dong, S. Deng, and F. Wang, "Some developments and new insights for environmental sustainability and disaster control of tailings dam," Journal of Cleaner Production, vol. 269, article 122270, 2020.

[8] D. Smart, S. Callery, and R. Courtney, "The potential for waste-derived materials to form soil covers for the restoration of mine tailings in Ireland," Land Degradation \& Development, vol. 27, no. 3, pp. 542-549, 2016.

[9] Y. Zhao, L. Zhang, J. Liao, W. Wang, Q. Liu, and L. Tang, "Experimental study of fracture toughness and subcritical crack growth of three rocks under different environments," International Journal of Geomechanics, vol. 20, no. 8, article 04020128, 2020.

[10] M. Fall, J. C. Célestin, M. Pokharel, and M. Touré, “A contribution to understanding the effects of curing temperature on the mechanical properties of mine cemented tailings backfill," Engineering Geology, vol. 114, no. 3-4, pp. 397-413, 2010.

[11] J. Ma, L. Dong, G. Zhao, and X. Li, "Qualitative method and case study for ground vibration of tunnels induced by faultslip in underground mine," Rock Mechanics and Rock Engineering, vol. 52, no. 6, pp. 1887-1901, 2019.

[12] Y. Zhao, Y. Wang, W. Wang, L. Tang, Q. Liu, and G. Cheng, "Modeling of rheological fracture behavior of rock cracks subjected to hydraulic pressure and far field stresses," Theoretical and Applied Fracture Mechanics, vol. 101, pp. 59-66, 2019.

[13] O. Nasir and M. Fall, "Modeling the heat development in hydrating CPB structures," Computers and Geotechnics, vol. 36, no. 7, pp. 1207-1218, 2009.

[14] H. Jiang, M. Fall, and L. Cui, "Freezing behaviour of cemented paste backfill material in column experiments," Construction \& Building Materials, vol. 147, pp. 837-846, 2017.

[15] E. Carlsson, Geochemical effects of soil cover remediation on sulphide-rich tailings at the Kristineberg mine, northern Sweden, Luleå Tekniska Universitet, 2000.

[16] N. A. Morales, D. Martínez, J. V. García-Meza et al., “Total and bioaccessible arsenic and lead in soils impacted by mining exploitation of Fe-oxide-rich ore deposit at Cerro de Mercado, Durango, Mexico," Environmental Earth Sciences, vol. 73, no. 7, pp. 3249-3261, 2015.

[17] H. B. Zhang and Y. J. Chen, "Study on the mechanism of backfill and surrounding rock of open stope during subsequent backfill mining," Advanced Materials Research, vol. 753-755, pp. 452-456, 2013. 
[18] A. Roshani, M. Fall, and K. Kennedy, "Impact of drying on geo-environmental properties of mature fine tailings predewatered with super absorbent polymer," International Journal of Environmental Science and Technology, vol. 14, no. 3, pp. 453-462, 2017.

[19] B. J. Kim, J. G. Jang, C. Y. Park, O. H. Han, and H. K. Kim, "Recycling of arsenic-rich mine tailings in controlled lowstrength materials," Journal of Cleaner Production, vol. 118, pp. 151-161, 2016.

[20] L. Cui and M. Fall, "An evolutive elasto-plastic model for cemented paste backfill," Computers and Geotechnics, vol. 71, pp. 19-29, 2016.

[21] L. Yang, J. Qiu, H. Jiang, S. Hu, H. Li, and S. Li, "Use of cemented super-fine unclassified tailings backfill for control of subsidence," Minerals, vol. 7, no. 11, p. 216, 2017.

[22] E. Yilmaz, T. Belem, and M. Benzaazoua, "Specimen size effect on strength behavior of cemented paste backfills subjected to different placement conditions," Engineering Geology, vol. 185, pp. 52-62, 2015.

[23] S. Ouellet, B. Bussière, M. Aubertin, and M. Benzaazoua, "Microstructural evolution of cemented paste backfill: mercury intrusion porosimetry test results," Cement and Concrete Research, vol. 37, no. 12, pp. 1654-1665, 2007.

[24] J. P. Doherty, "A numerical study into factors affecting stress and pore pressure in free draining mine stopes," Computers and Geotechnics, vol. 63, pp. 331-341, 2015.

[25] D. M. Mchaina, S. Januszewski, and R. L. Hallam, "Development of an environmental impact and mitigation assessment program for a tailings storage facility stability upgrade," International Journal of Surface Mining, Reclamation and Environment, vol. 15, no. 2, pp. 123-140, 2001.

[26] X. Li, J. Du, L. Gao et al., "Immobilization of phosphogypsum for cemented paste backfill and its environmental effect," Journal of Cleaner Production, vol. 156, pp. 137-146, 2017.

[27] H. Lu, C. Qi, Q. Chen, D. Gan, Z. Xue, and Y. Hu, “A new procedure for recycling waste tailings as cemented paste backfill to underground stopes and open pits," Journal of Cleaner Production, vol. 188, pp. 601-612, 2018.

[28] W. Sun, H. Wang, and K. Hou, "Control of waste rock-tailings paste backfill for active mining subsidence areas," Journal of Cleaner Production, vol. 171, pp. 567-579, 2018.

[29] M. Helinski, M. Fahey, and A. Fourie, "Numerical modeling of cemented mine backfill deposition," Journal of Geotechnical \& Geoenvironmental Engineering, vol. 133, no. 10, pp. 13081319, 2007.

[30] D. Q. Deng, L. Liu, Z. L. Yao, K. I. I. L. Song, and D. Z. Lao, “A practice of ultra-fine tailings disposal as filling material in a gold mine," Journal of Environmental Management, vol. 196, pp. 100-109, 2017.

[31] M. Edraki, T. Baumgartl, E. Manlapig, D. Bradshaw, D. M. Franks, and C. J. Moran, "Designing mine tailings for better environmental, social and economic outcomes: a review of alternative approaches," Journal of Cleaner Production, vol. 84, pp. 411-420, 2014.

[32] Z. X. Liu and X. B. Li, "Study on fractal gradation of tailings and knowledge bank of its cementing strength," Chinese Journal of Rock Mechanics \& Engineering, vol. 24, pp. 1789-1793, 2005.

[33] F. K. Mulenga, A. A. Mkonde, and M. M. Bwalya, "Effects of load filling, slurry concentration and feed flowrate on the attainable region path of an open milling circuit," Minerals Engineering, vol. 89, pp. 30-41, 2016.
[34] R. J. Mitchell, R. S. Olsen, and J. D. Smith, "Model studies on cemented tailings used in mine backfill," Canadian Geotechnical Journal, vol. 19, no. 1, pp. 14-28, 1982.

[35] A. Tariq and E. K. Yanful, "a review of binders used in cemented paste tailings for underground and surface disposal practices," Journal of Environmental Management, vol. 131, pp. 138-149, 2013.

[36] A. P. Puga, L. C. A. Melo, C. A. de Abreu, A. R. Coscione, and J. Paz-Ferreiro, "Leaching and fractionation of heavy metals in mining soils amended with biochar," Soil \& Tillage Research, vol. 164, pp. 25-33, 2016.

[37] X. Wang, W. Xiao, X. Wang, and Z. Xiao, "Study on rheological properies of full tailing paste filling slurry of Jinchuan mine," Mining \& Metallurgical Engineering, vol. 22, no. 3, pp. 13-16, 2002.

[38] M. Cai, J. Wang, and S. Wang, "Analysis of energy distribution and prediction of rock burst during deep mining excavation in Linglong gold mine," Chinese Journal of Rock Mechanics \& Engineering, vol. 20, no. 1, pp. 38-42, 2001.

[39] D. F. Huber and N. Vandapel, "Automatic three-dimensional underground mine mapping," The International Journal of Robotics Research, vol. 25, no. 1, pp. 7-17, 2006.

[40] M. A. Hai-Tao, Y. F. Liu, and H. U. Jia-Guo, "Study on Gob detection and visualization of three-dimensional model based on C-ALS," Journal of Safety Science \& Technology, vol. 6, no. 3, pp. 38-41, 2010.

[41] H. Z. Xiao, X. M. Liu, B. B. Dai, J. H. Chen, and W. G. Luo, “3D detection and safety analysis for extra-large Karst Cave based on C-ALS," Mining \& Metallurgical Engineering, vol. 35, no. 4, pp. 12-16, 2015.

[42] L. F. Zeng, L. I. Xi-Bing, X. L. Liu, D. F. Shi, and M. Huang, "Research on visualization of three-dimensional model for underground mind-out area in Luanchuan Sandaozhuang Mo mine," Mining \& Metallurgical Engineering, vol. 28, pp. 31-33, 2008.

[43] Y. Zhao, L. Zhang, W. Wang, Q. Liu, L. Tang, and G. Cheng, "Experimental study on shear behavior and a revised shear strength model for infilled rock joints," International Journal of Geomechanics, vol. 20, no. 9, article 04020141, 2020.

[44] S. Huang, K. Xia, and L. Qiao, "Dynamic tests of cemented paste backfill: effects of strain rate, curing time, and cement content on compressive strength," Journal of Materials Science, vol. 46, no. 15, pp. 5165-5170, 2011.

[45] C. Liang and M. Fall, "Multiphysics modeling and simulation of strength development and distribution in cemented tailings backfill structures," International Journal of Concrete Structures \& Materials, vol. 12, p. 25, 2018.

[46] R. Wu, H. Liu, G. Sun, X. Wang, and M. Branch, "Curing and backfilling test of surface subsidence pit by directly discharging tailings in Meishan Iron Mine," Metal Mine, vol. 46, no. 10, p. 176, 2017.

[47] H. J. Wang, "Application of high water rapid solidified material to high density fill of the tailings cemented," Industrial Minerals \& Porocessing, vol. 12, 2000.

[48] X. Ke, X. Zhou, X. Wang, T. Wang, H. Hou, and M. Zhou, "Effect of tailings fineness on the pore structure development of cemented paste backfill," Construction \& Building Materials, vol. 126, pp. 345-350, 2016.

[49] L. M. Arya and J. F. Paris, "A physicoempirical model to predict the soil moisture characteristic from particle-size 
distribution and bulk density data," Soil Science Society of America Journal, vol. 45, no. 6, pp. 1023-1030, 1981.

[50] T. Wichtmann and T. Triantafyllidis, "Influence of the grainsize distribution curve of quartz sand on the small strain shear modulus Gmax," Journal of Geotechnical \& Geoenvironmental Engineering, vol. 135, no. 10, pp. 1404-1418, 2009.

[51] M. Benzaazoua, M. Fall, and T. Belem, "A contribution to understanding the hardening process of cemented pastefill," Minerals Engineering, vol. 17, no. 2, pp. 141-152, 2004.

[52] G. C. Li, H. J. Wang, A. X. Wu et al., "Gravity transport law of paste based on inclined pipe experiment," Chinese Journal of Nonferrous Metals, vol. 24, pp. 3162-3168, 2014.

[53] X. B. Li and Z. X. Liu, "On mechanics of high consolidated tailings backfill and cement-tailing ratios optimization with game tree," Journal of Safety \& Environment, vol. 4, no. 4, pp. 87-90, 2004.

[54] T. Liu, Filling mining technology and its application, Metallurgical Industry Press, Beijing, 2001.

[55] R. Zhang and G. He, Mining engineering design manual, Coal Industry Press, Beijing, 2018.

[56] R. Knutsson, Tailings Dam Performance, Luleå University of Technology, 2015. 